\title{
The use of story to teach religious education in the early years of primary school: a systematic review of the literature
}

\author{
Kerrin Huth ${ }^{1}$ (D) Raymond Brown ${ }^{2} \cdot$ Wayne Usher ${ }^{2}$ (D)
}

Accepted: 20 May 2021 / Published online: 16 June 2021

(c) Australian Catholic University 2021

\begin{abstract}
This systematic quantitative literature review explores the use of story in early childhood religious education to inform the research question "What are the pedagogical benefits of using story in religious education in the early years of primary school?" Searches were conducted across multiple databases and individual journals for publications dated from 1970 to 2019. Literature on the key areas of (1) early childhood, (2) story and (3) religious education were analysed to understand their unique perspectives and ways they overlap and connect, with an emphasis on seeking literature which connected all three areas. The study revealed the areas of religious education, the use of story and the field of early childhood as three distinct areas of research with connection points, and gaps in the literature connecting the pedagogical use of story for religious education in early primary education. The literature identifies the use of story as effectively engaging and connecting children to religious education in a pedagogically appropriate way for the early childhood age group. Further to this, benefits were found not only in faith development and biblical literacy, but also in learning, literacy development, empathy, and engagement with differing worldviews. The Australian context was a focus of the literature review providing insight for religious education in Christian schools which may be applied to other contexts in public schools, or internationally.
\end{abstract}

Keywords Religious education $\cdot$ Early childhood $\cdot$ Story $\cdot$ Systematic $\cdot$ Primary school

\section{Introduction}

This Systematic Quantitative Literature Review [SQLR] explores the literature on the use of story in religious education and focused on the educational method or pedagogy drawn on to connect the differing fields of early childhood, story and religious education. The literature within each field is considerable, revealing that these three distinct areas are specialties in their own right, and therefore requiring separate investigation to gain an understanding of each. Following this, the identification of the significant areas of overlap

Kerrin Huth

Kerrin.huth@griffithuni.edu.au

Griffith University, Gold Coast, QLD, Australia

2 School of Education and Professional Studies, Griffith University, Gold Coast, QLD, Australia 
inform the research question, "What are the pedagogical benefits of using story in religious education in the early years of primary school?" Clarification of the terminology was necessary to establish an understanding of early childhood, story and religious education. Subsequent filtering of search results was also necessary to define their relevance to the research question.

This paper identifies elements of influence (curriculum and pedagogy) as the driving factors in establishing good practice in early childhood settings and highlights the benefits of the use of story as a pedagogical support in early childhood, in both literacy development, and engagement with inquiry learning. Further benefits are found in religious education with differing uses of story contributing to faith practices (or expressions of the Christian faith), biblical literacy, and engaging with different worldviews (Mitchell, 2004). In order to define the parameters of the research, the literature review includes a focus on one school system's Religious Education curriculum within the Australian context.

\section{Systematic quantitative literature review methodology}

Systematic Quantitative Literature Review [SQLR] is a method that filters research through a systematic process which involves quantitatively selecting and assessing literature to produce a database which identifies trends and gaps in the literature (Pickering \& Byrne, 2014). It uses explicit methods to systematically provide a reliable view of the topic while reducing bias (Social Science Research Unit, 2019). For this review, published research articles, books and literature reviews were identified through searches of electronic databases including Pro Quest, ERIC, EBSCO, and Education. Further papers were identified through searching specific reference lists and citation records or by searching national and international religious education journals.

Three general areas (refer Fig. 1: Areas of research) provided a starting point for the search, each with a specific set of key words to ensure a broad range of relevant papers were captured.

Fig. 1 Areas of research

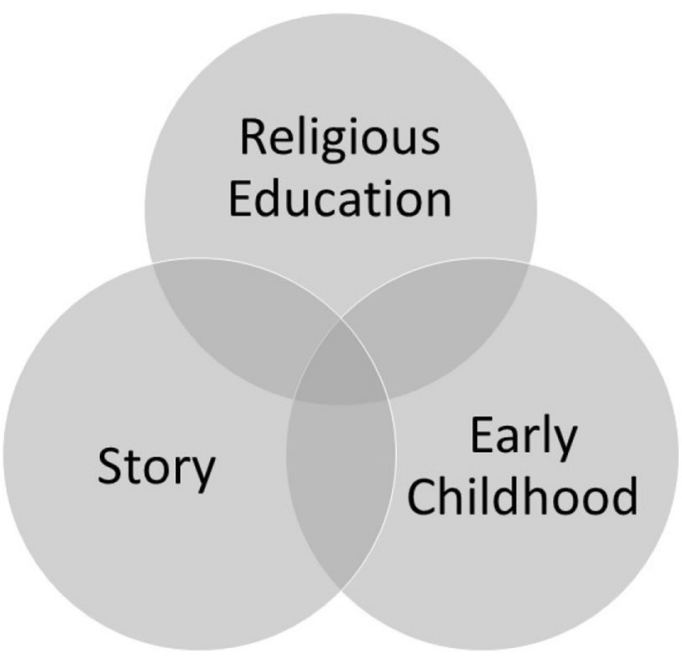


Specific key words for each area included:

- Religious Education: religious education, Catholic education, faith based, religion, religious

- Early Childhood: early childhood, early years, teacher(s), primary school, teaching

- Story: story, storytelling, story telling

The following flow chart provides the sequence of literature analysis and selection of papers for the literature review (refer Fig. 2: Research flow chart).

Fig. 2 Research flow chart

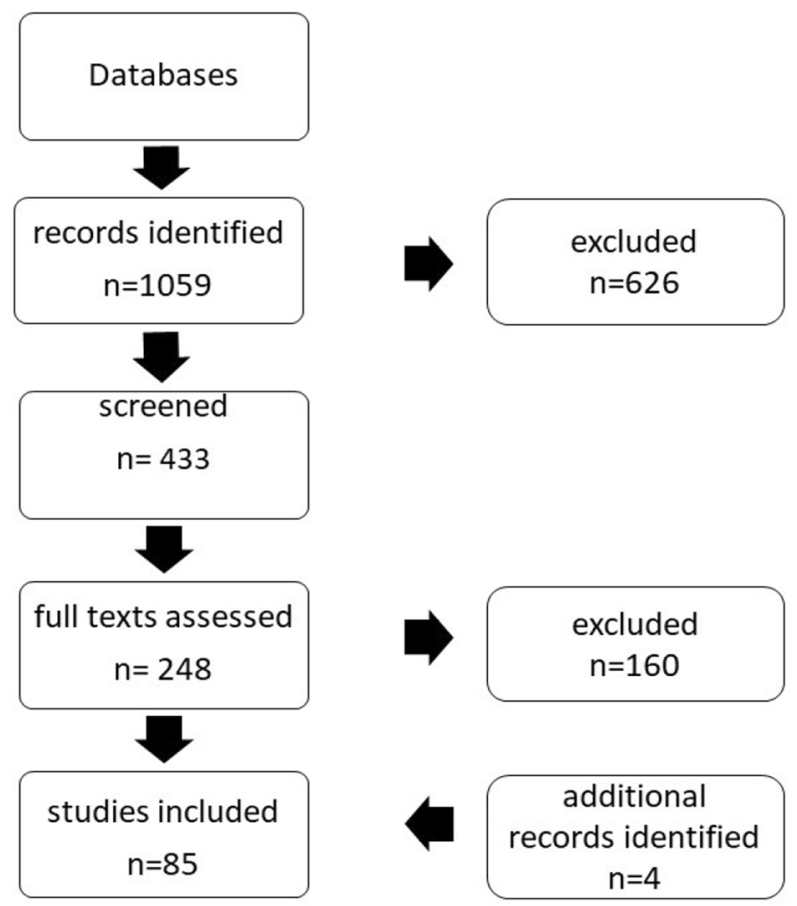

The searches revealed a broad spectrum of works with topics ranging from religion, teaching religion, personal story, literature, pedagogy and storytelling. Each search produced a varying number of papers, with the vast number not dealing specifically with all three elements. For example, many titles using 'story' would infer relation to either early childhood or religion but seldom both. A strict adherence to all three fields yielded few results and in some searches none at all. Searching only the abstracts again proved ineffective. As these refinements did not lead to targeting the specific topic of the use of story in religious education in early childhood classrooms, each topic needed refinement to narrow the results. This proved to be a more effective method of locating relevant documents. With each field being so diverse, papers were sought to refine the definitions and connections between the areas. Finally, further refinement was necessary to establish the list of papers which would fit the aims of the literature review, and so more specific topics were used as criteria for inclusion: 
- Early childhood pedagogy and characteristics: effective pedagogy, policy documents, primary school vs early childhood settings,

- Religious education in early childhood: varied settings, focus on school, change in delivery methods, Australian perspective

- Story in education: across curriculum areas, definitions, literature, benefits, literacy, use in religious education including specific use of methods, Godly Play, spirituality, spiritual development

Identifying where and how the categories overlapped, provided a guide for the selection of the most relevant papers to be included in the literature review (refer Fig. 3: Refinement of search topics).

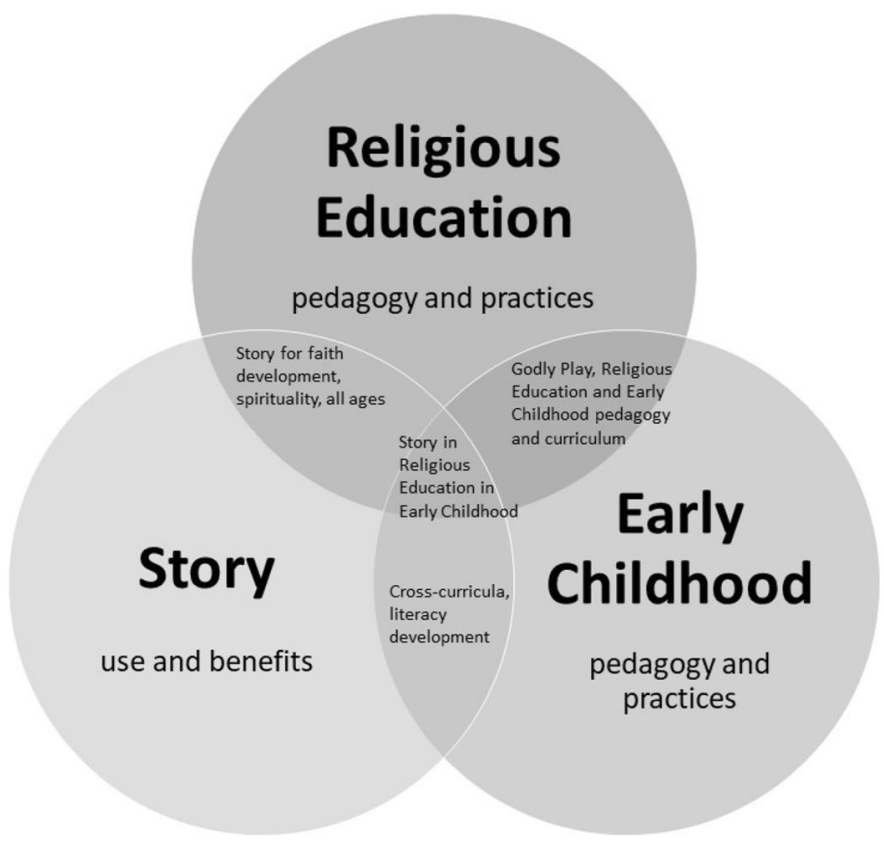

Fig. 3 Refinement of search topics

Although this topic has relevance internationally within the context of primary school religious education, Australian research provides a unique insight into local practices, and therefore was considered important for inclusion due to its relevance to the research, for which the review was conducted. Of the papers found in the broad areas of searching, 248 papers were filtered for full assessment of relevance to the research topic under the following categories (refer Table 1: Relevance of topic). 
Table 1 Relevance of topic

\begin{tabular}{ll}
\hline General topic & $\begin{array}{l}\text { Num- } \\
\text { ber of } \\
\text { papers }\end{array}$ \\
\hline Early childhood pedagogy and nature & $(54)$ \\
Religious education in early childhood & $(65)$ \\
Story in early childhood & $(53)$ \\
Story in religious education & $(76)$ \\
Total papers for refinement & 248 \\
\hline
\end{tabular}

Of these 248 texts assessed, 160 were filtered as either not relevant or not sufficiently related to the research question. Finally, 85 papers were selected for this literature review. Further analysis of these documents revealed their relevance to the specific topic and highlighted key authors or publications and identified which papers would be most relevant as indicated in the centre of the Venn diagram (refer Fig. 3: Refinement of search topics). Documents were initially evaluated on their relevance to each general field according to the main emphasis of the article. They were then evaluated for their focus on specific topics. A score out of six (one point for each category) was given to each document to evaluate its significance and relevance to each of the following categories:

Main emphasis of article:

- Early childhood pedagogy

- Religious education

- Story

Specific relevance:

- Story in early childhood

- Story in religious education

- Religious education in early childhood

Documents were allocated one point for each category if it was deemed a significant contribution (refer Table 3: Score of relevance). Additional records for further assessment were identified through general searches and following citation and referencing lists of significantly relevant authors.

\section{Results}

The literature search yielded varying results with a wealth of resources supporting each main focus area. The depth of research provided a great understanding of the nature of early childhood, story and religious education and therefore it was necessary to narrow the search to find the connections between them. Frequently the searches revealed a connection between two of the areas, rather than a connection between all three. Author studies proved valuable as their reference and citations lists were followed to reveal more sources. The selected papers indicate research in these fields as significant in Australia, USA and UK as featured in Table 2: Distribution of papers. 
Table 2 Distribution of papers

\begin{tabular}{lclc}
\hline Country & $\begin{array}{l}\text { Low signifi- } \\
\text { cance }\end{array}$ & $\begin{array}{l}\text { High Signifi- } \\
\text { cance }\end{array}$ & Total of papers \\
\hline Canada & 2 & 0 & 2 \\
USA & 21 & 4 & 25 \\
UK & 11 & 1 & 12 \\
South Korea & 1 & 0 & 1 \\
South Africa & 1 & 0 & 1 \\
Australia & 32 & 12 & 44 \\
\hline
\end{tabular}

Of the 85 papers included in this literature review, only seven had significant relevance to the research topic, highlighting a gap in the current research connecting story as pedagogically beneficial for teaching religious education in early childhood classrooms (refer Table 3: Score of relevance).

Table 3 Score of relevance

\begin{tabular}{lc}
\hline Score & $\begin{array}{l}\text { Number } \\
\text { of papers }\end{array}$ \\
\hline 6 & 7 \\
5 & 6 \\
4 & 4 \\
3 & 43 \\
2 & 4 \\
1 & 21 \\
\hline
\end{tabular}

Of the seven most significant papers, five came from the same author, who also featured in the second group of relevant papers. Of the seventeen papers of greatest significance, twelve were written by Australian authors (two were Australian curriculum or departmental documents), four were from the USA and one from the UK. Key Australian authors working in the field of religious education in the early childhood sector include Jan Grajczonek and Brendan Hyde, both with significant research contributions over several years and this was reflected in the filtering process. Their papers, citations and references provided a useful source for connecting the key elements of the literature review.

The literature search revealed publications in a range of disciplines with journals ranging from religious education, early childhood, social sciences, psychology, theology and teaching journals. Several authors published works in editorial books on a specific theme such as religious education, literacy or pedagogical practice. The majority of the selected papers were theoretical with some empirical studies on various topics related to the overall research, and policy or departmental documents included for reference (refer Table 4: Types of papers). In this review, empirical refers to research based on observation or direct experience (Punch, 2000). 
Table 4 Types of papers

\begin{tabular}{lll}
\hline Document & Topics & $\begin{array}{l}\text { Number included } \\
\text { in literature } \\
\text { review }\end{array}$ \\
\hline Policy or departmental documents & $\begin{array}{l}\text { Early childhood pedagogy, religious education } \\
\text { curriculum } \\
\text { Theoretical research }\end{array}$ & $7(8 \%)$ \\
& $\begin{array}{l}\text { Stories and literature, technology, Godly Play, } \\
\text { drama, curriculum, diversity, making meaning, } \\
\text { teaching scripture, early childhood pedagogy, } \\
\text { language development, spiritual development, } \\
\text { religious education pedagogy }\end{array}$ & $57(67 \%)$ \\
Empirical research & $\begin{array}{l}\text { Religion and childhood development, Godly Play, } \\
\text { art in early childhood, leadership, religious iden- } \\
\text { tity, early childhood, story and spirituality, early } \\
\text { childhood pedagogy and curriculum, reading, }\end{array}$ & $25 \%)$ \\
textbooks in religious education & \\
Total documents included & & \\
\hline
\end{tabular}

This literature search highlights the strength of theoretical research in all three areas with different aspects explored in depth. Similarly the empirical research, although not as prevalent, has a focus on a variety of areas within early childhood and religious education. It also highlights the gaps in research which connect early childhood pedagogy, story and religious education. The following section outlines key insights from the literature review relevant to the use of story as a pedagogically beneficial tool for teaching religious education in the early years of primary school.

\section{Insights}

The selected literature revealed insights on the unique nature of early childhood and suggested implications for pedagogy and curriculum when developing age-appropriate learning. It also revealed a wide range of terminology associated with story and therefore a definition of terms was necessary to define the parameters for the research. The investigation into religious education covered the broad range of purposes and approaches used in a variety of settings. Narrowing the focus specifically to the use of story within religious education revealed its contribution to faith practices or expression of faith, development of literacy and varied use of stories and story-telling methods. The following sections outline the insights from the review of the selected literature on (1) learning in early childhood, (2) story and (3) religious education.

\subsection{Learning in early childhood}

The literature on early childhood provides a broad insight into the unique nature of this age group and the way they learn. Three crucial elements regarding learning in early childhood have emerged from the research over time: learner centred pedagogy, scaffolding of learning, and learners actively engaged in their learning, with all three needing to be incorporated into the pedagogical framework of the early childhood setting (Department of Education \& Training, 2015). For the purposes of this research, pedagogy refers to both the thinking behind the learning experiences, and the teaching strategies (Moyles et al., 2002). 


\subsubsection{Learner-centred pedagogy}

Learning in the early years is considered complex today, with the child taking an active role in their learning and construction of knowledge, rather than being seen as a blank slate (Council of Australian Governments, 2010; Grajczonek \& Hanifin, 2007). Recent attention on today's learners indicates they are greater risk takers, will learn early on from failures, and take meaning from different areas to build their understanding (Casson, 2011; McCrindle, 2018a, 2018b). Studies show a well-defined curriculum and successful implementation incorporates a wide range of experiences which provide learners with greater opportunities to explore multiple perspectives and develop social problem-solving abilities (Child Australia, 2017; Council of Australian Governments, 2017; Department of Education \& Training, 2015; Kim, 2016; Lillard, 1998). Further to this, a learner centred curriculum responds to the unique developmental needs and interests of individual children (Catholic Education Council, 2001). Grajczonek (2017) emphasises that the image of the contemporary child both underpins and determines religious education curriculum development and that the philosophy which underpins that curriculum must be defined. Curriculum, informed by sociocultural theory, transforms children from within, where learning is socially constructed with meaningful content that enables children to transform their own world (Grajczonek, 2017). The socio-cultural dimension of children's learning has implications for pedagogy in the religious education classroom (Grajczonek, 2013). Children's diverse backgrounds need to be taken into account with a balance of pedagogical interaction (responding to children's learning) and pedagogical framing (planning and resourcing) to provide an effective setting for children's learning (Grajczonek, 2013; Siraj-Blatchford $\&$ Sylva, 2004). Although these ideas of religious education curriculum lie within the Australian Catholic context, the underlying ideals are important for consideration in other religious education contexts. Overall, a well-designed curriculum for early childhood is underpinned by theory and practice to meet the diverse needs of learners (Grajczonek, 2017).

\subsubsection{Scaffolding learning}

Pedagogy influences learning outcomes, and educators are thoughtful and intentional when making decisions about curriculum and strategies which support children's learning (Boyd \& Cutcher, 2015; Kilderry, 2015). Systemic documents, such as policy and curriculum frameworks, provide rich guidelines on decision making, planning, implementing and evaluating learning. Such documents provide a reflection point for pedagogical practices and being intentional about what is included and excluded (Council of Australian Governments, 2010, 2017). When teachers reflect on daily practice to ensure consistency with early childhood practice, and make improvements in teaching and learning, it has a positive impact on students (Carroll-Lind et al., 2016; Jones et al., 2017).

Pedagogical decisions impact the learning environment including both physical and social spaces. The use of agile (moveable, flexible and adaptable) learning spaces supports the changing nature of curriculum delivery, as reflected in the move from an industrial model of teaching to one which will meet the needs of current learners. The learning environment needs to further reflect this style of learning. It should allow learners to make connections within the classroom and beyond through problem solving, peer to peer learning, collaboration, online connection and visual, and hands on learning using multiple digital platforms to scaffold and support the learning (Department of Education \& Training, 2015). 


\subsubsection{Engagement of learners}

As children engage in opportunities for play, exploration and experimentation they begin to make sense of themselves and the world around them, develop confidence and engagement with learning, and through the social environment engage with multiple perspectives (Cohrssen et al., 2016; Department of Education \& Training, 2015; Kilderry, 2015; Lillard, 1998; Meehan, 2007). Studies on play (including role play and story retell), indicate that play provides opportunities to develop creative thinking, and that teachers can support children to enhance thinking and develop their skills (Grajczonek, 2007; Leggett \& Newman, 2017). Children create knowledge as they play, interacting with their environment, other children, objects and their teachers; playing a pivotal role in their own learning (Leggett \& Newman, 2017; Pollock et al., 2017). These studies effectively gathered information from a combination of document analysis, interviews with educators and children, and collections of artefacts, providing a rich diversity of data from which to draw their conclusions. While these studies focused more generally on play, further research into the use of story through play would provide additional insight. Similarly, research shows that effective literaturebased activities allow all children to engage with the curriculum including students with special needs (Zeece et al., 2004).

Together, these studies on learning in early childhood raise awareness about the decisions teachers make regarding pedagogy, and how the choices they make about how to teach the curriculum, has a significant influence on children's learning.

\subsection{Story}

The literature revealed a variety of definitions and uses of the term story, along with a range of associated terminology. Story incorporates a variety of genres including picture books, traditional literature, modern fantasy, contemporary realistic fiction, digital stories or games and information books. These terms provide a useful context for this research which refers to the use of story as encompassing these genres and strategies, including children's literature, personal story, biblical text and methods of storytelling including role play and other strategies and techniques such as Godly Play (which will be outlined in a later section).

Children make sense of their world and feed their imagination through stories (Laminack, 2016; Simpson, 2016). There is also a distinction between reading a story, being read to and telling your own story. Retelling can help children try out their ideas in a safe space (Crain, 2007; Ewing \& Saunders, 2016; Grajczonek, 2013). Stories are important in the early childhood setting. "Stories matter because our wisdom and intuitive understanding is woven into the stories we know, tell and live through (Pawson, 2014, p. 52)". Shaw (1999) echoes this sentiment, emphasising that stories are powerful and a primary human activity.

\subsubsection{Storytelling methods}

The telling of a story itself must be captivating, engaging listeners emotionally and building empathy. Familiarity with the story can enable this, rather than a simple reading of the story (Leary, 1986). For story to be effective it must entertain, enrich, inspire curiosity and imagination, and be told frequently (Leary, 1986; Pawson, 2014; Richards, 2007). It is important to consider the selection of a story, preparing the learners to listen and 
participate, as well as considering the timing of the story (Shaw, 1999). Further to this, effective story-telling, requires hard work, discipline and practice (Berryman, 1991; Grajczonek \& Ryan, 2009; Shaw, 1999). The relationship between the storyteller and the listener is also important. A gifted storyteller or one who develops a personal relationship with the listener, adds power to the story (Hoopes, 2013).

Dramatic play is a significant element of early years learning and provides a natural point of access to story in religious education (Catholic Education Council, 2001; Council of Australian Governments, 2010, 2017). Dramatic storytelling allows learners to connect deeply with the characters, empathising with them and understanding their behaviours more fully. Grajczonek (2007) found that teachers can use dramatic storytelling as a tool for assessing student understanding. Puppetry can support dramatic storytelling, providing visual and kinaesthetic experiences, engaging learners in maintaining their attention as well as providing them with the opportunity for retelling stories (Richards, 2007). Enacting a story through movement, art, singing and music allow the senses to be engaged and enhance the learning experience (Shaw, 1999).

\subsubsection{Benefits of story}

The literature included a range of storytelling modes from dramatic storytelling, to books and electronic media, with each generating a different experience for learners. "A story can insert an image into the heart of the listener, where it can take shape and grow"; engaging learners in critical thinking, curiosity and exploration (Jacobs-Sife, 2011, p. 29). Learners build literacy and social skills through engagement in a variety of texts in a literacy-rich environment. As Hynes-Berry (2012) indicates, making personal connections to the story is important for learners' understanding and these connections could be text to text, text to self, text to graphics and text to world. The benefits increase when story is paired with student-centred inquiry where children are naturally curious and their questions allow for more ownership and collaboration (Ewing \& Saunders, 2016; Hynes-Berry, 2012). Open ended questions elicit more elaborate responses and recall is further enhanced when used during dramatic play (Siegel-Hawley, 2012). Similarly, research conducted by Ness (2016) in the early years of primary school revealed inquiry based reading allowed the development of student generated questions. This in turn provided cognitive and motivational benefits for students.

Reading to children is most effective when combined with high-quality discussion, focusing on the interests and needs of the learners. Being immersed in a literacy rich environment helps to develop the skills and understandings needed for independent reading and comprehension with shared book reading also prominent in language and literacy development (Anderson, 2015; Anderson et al., 2012). The reading of literature becomes collaborative in the classroom setting as children respond to the text together (Trousdale, 2009). Initially, a broad definition of children's literature is helpful for understanding the scope of what might be referred to as story.

Children's literature is the complete large body of literature that children have embraced. It becomes their own personal literature because it belongs to children rather than parents, teachers, preachers, or even the authors. (Saracho, 2012)

According to Saracho (2012), children's literature allows opportunities for play through interpretation, storytelling, improvisation and collaboration and those which engage in education, fantasy and moralistic combinations provide the children with profound and 
long remembered experiences. Play is an important context for developing literacy skills and these increased where the play was enriched by literacy resources (Department of Education \& Training, 2015). Similarly, research on dramatic storytelling focussed on the benefits for literacy development as expanding vocabulary, listening and speaking skills. The development of literacy in the early years was considered vital for future school achievement success (O'Neill et al., 2016). Further research on picture books revealed children rely on words and pictures for a full understanding of the meaning. While wordless picture books may be effective, teachers are more likely to use picture books with words. The interplay of these elements makes them a rich resource (Hateley, 2014). Innovations in technology and ease of access in classrooms, enable electronic books to feature more prominently (Cruz \& Snider, 2009; Hateley, 2014; McCrindle, 2014). Technology brings a change to the use of traditional literary texts with interaction encouraged through touch and voice recording (Hateley, 2014). The verbal text however, is still highly valued with children listening to others' stories and creating their own (Cruz \& Snider, 2009; Hateley, 2014).

As the previous research reveals, the benefits of story flow from children making a personal connection through experiencing story, enabling them to further develop literacy skills, collaborate and engage in critical thinking and inquiry.

\subsection{Religious education}

The third area of exploration in the systematic literature review is that of the use of story in religious education. In this context, religious education refers to the formal curricular program used in primary schools to engage learners in the teachings, culture and history of the Christian church and to explore how the Christian faith relates to all aspects of people's lives. Although a faith response is not an expectation of the formal curriculum, the religious education program is set within the context of the whole Christian education experience of the school where the Christian faith may be actively nurtured and expressed (Lutheran Education Australia, 2015). Religious education is an area in which faith-based schools invest time into research to understand the needs of the learner in the light of faith development (Goldburg, 2008; Grajczonek, 2013, 2017; Grajczonek \& Hanifin, 2007; Hyde, 2005, 2010; Meehan, 2007; Ryan, 2007; Rymarz \& Engebretson, 2005). The literature in this area revealed the contribution story makes to faith practice (or expressions of the Christian faith) and the variety of methods and stories used in religious education classes. Core policy and curriculum documents from schooling systems in Australia, and research on religious education reveal the aims of developing literacy (including biblical literacy), engaging with biblical story in various ways, valuing and respecting diversity and contributing to faith development (Blevins, 2007; Christian, 2008; Gooderham, 1994; Grajczonek, 2013, 2017; Hyde, 2005; Hynes-Berry, 2012; Lutheran Education Australia, 2013, 2015). Research also shows that religious education will differ in the early years, reflecting age-appropriate pedagogy through the inclusion of real-life activities and hands-on experiences, allowing for discovery and exploration through the senses (Meehan, 2007; Ryan \& Stower, 1998). It is therefore important that methods and strategies take into account the learner's existing knowledge, experiences, questions, community and real life experiences and that scaffolding is provided (Grajczonek \& Hanifin, 2007; Meehan, 2007). Further research revealed the connections between various systemic policy documents and 
pedagogy, with the role of the teacher as key in promoting children's learning (Grajczonek, 2013).

Christian Studies is the formal religious education program of Lutheran Education Australia. Systemic Lutheran Education documents reflect beliefs about the purpose and pedagogy of Christian Studies, where the pedagogy provides a connection between the learner's world and the curriculum framework. This enables learners to engage in their own journey of discovery to make sense of the world around them (Lutheran Education Australia, 2013, 2015). The curriculum framework encourages teachers to consider the diverse range of learners and the importance of providing learning opportunities which cater to this diversity. Experiences must be intellectually rigorous, engaging, learner-centred, invite challenge and growth, and promote the sharing of stories and ideas while being grounded in theological understanding (Lutheran Education Australia, 2015). Pedagogical approaches encourage access to a range of ways to make meaning, while encouraging deep thinking, through the processes of inquiry, reflection and action. The learning environment is supportive, inclusive and encourages collaboration, allowing learners to explore their own spirituality and broaden their worldview (Lutheran Education Australia, 2015).

\subsubsection{Story in religious education}

Much of the research on story in the field of religious education focuses on the connection of story to children's spirituality rather than on the benefits of story when used as a pedagogical support for teaching religious education (Grajczonek, 2007; Grajczonek \& Ryan, 2009; Grajczonek \& Truasheim, 2017; Hyde, 2005, 2010; Meehan, 2007; Ryan, 2007). The literature also highlights the unique nature of both early childhood and religious education, with age-appropriate pedagogy considered important (Department of Education \& Training, 2015; Grajczonek, 2013; Grajczonek \& Hanifin, 2007; Lutheran Education Australia, 2015; Meehan, 2007; Ryan, 2007). The use of story can effectively speak into both spaces, addressing their unique needs and characteristics (Grajczonek \& Ryan, 2009).

Ryan's (2007) research into the theorists who inform early years religious education, reveals an intense interest in stories and how these shape moral imagination. As children encounter their own stories and stories of others, they listen and reflect, developing their sense of wonder about biblical stories (Jacobs-Sife, 2011). Students do not need to know stories by heart, but rather engage with them and ask questions to develop religious literacy (Goldburg, 2004; Hansell, 2015). The work of Arthur (1988) suggests that stories in religious education have great value with previous recognition of their worth in various journals and in practice, yet he also suggests they are still seen as trivial diversions. To further elaborate, Arthur recognises three significant benefits of story as: empathy, cognitive potential, and an effective way of dealing with abstract or difficult to describe concepts. Stories provide the opportunity to engage in empathy and see things from a unique perspective with which the reader may not be familiar. The cognitive potential of story to unlock a new dimension to knowledge may not engage the reader in new facts, however it opens a depth of understanding to the situation. Finally, Arthur states there is value in the use of story to provide a subtle and effective approach to things which can be difficult to describe. It can be thought provoking and is used extensively in almost every religious tradition in this way. When balancing empathy and reasoned investigation; utilising story's cognitive potential with other ways of knowing; and engaging in thought provoking exploration of religious issues, then "there is no reason why story should not be seen and used as one of the most important vehicles of communication open to the religious educator." 
(Arthur, 1988, p. 126) This work is further supported by the research which found story was used to help explore life's big and often most difficult questions (Freitas, 2005; JacobsSife, 2011). Stories open provocative questions and emotion with which children can investigate possible inquiries, struggle with issues and engage in religious imagination. As the evidence reveals, story can be used effectively in religious education to connect students personally, while building empathy, contributing to faith practice (or expressions of the Christian faith) and developing religious literacy.

4.3.1.1 Developing literacy Story in early childhood assists with the development of language and literacy and this is also the case when used in religious education. Biblical literacy involves interpreting and discussing the meaning and significance of the biblical text, similar to how other forms of literary text are approached and explored (Stack-Nelson, 2014; Welbourne, 2003). Understanding key terms, symbols and metaphors, as well as connecting with the text, are vital when studying biblical text to understand the original and contemporary meaning, and how it applies in the current context (Christenson, 2004; Lutheran Education Australia, 2015; Stack-Nelson, 2014; Welbourne, 2003). Grajczonek and Hanifin's (2007) research identified that stories in religious education develop language skills, which in turn builds literacy skills, as well as developing religious vocabulary and literacy. Biblical stories can provide a stimulus for dramatic play and the rich language which develops can provide the basis for the child's own retell. Similarly, research into Godly Play reveals the value of this method of storytelling for developing biblical and religious literacy (Hyde, 2010). The social nature of the educational setting in which language features heavily provides the ideal space in which literacy development can flourish (Grajczonek, 2013; Liddy, 2009; Ryan, 2007; Vygotsky, 1978).

4.3.1.2 Biblical story The aim of Christian Studies is to give students a clear understanding and appreciation of the Christian story through an exploration of the biblical text and Christian literature (Lutheran Education Australia, 2015). The Bible is the primary source of text for Christian Studies. Biblical stories are used extensively as teachers aim to develop biblical literacy, taking learners from basic recall of facts to an in-depth study of biblical text (Lutheran Education Australia, 2015). The interpretation of scripture and how we are to understand it in the current context, moves beyond an academic interpretation to allow learners to engage personally with the text (Lutheran Education Australia, 2015; Shaw, 1999). Through this exploration learners use language, symbols and imagery to read and interpret the texts and critical reflection on the text helps learners to understand their experiences through insights into Christian history (Lutheran Education Australia, 2015). A key element of biblical literacy is the selection of the text. Teachers must be discerning when choosing an appropriate text to suit the age of the learners and allow them to engage, explore and connect with the text. Teachers in the early years may select a children's version of the biblical story to provide ease of access for the learners. Teachers need to assess which version provides sufficient information and accuracy, being careful to avoid versions which may lead to misconceptions or omission of key elements or reducing them to mere moral lessons (Dalton, 2007; Pawson, 2014; Schachter, 1985). Teachers should always read the full version of text for themselves to provide them with the relevant background information (Lutheran Education Australia, 2015). Learners need to be engaged in exploration of biblical story which allows for wondering, critical thinking, making meaning and reveals the human story (Christenson, 2004). 
Liddy's research (2009) found that teaching with biblical story must be innovative and creative; allowing for learners to personally interact and yet be sensitive to the age-specific needs of the learners. The text can be unpacked exploring the world behind the text (context, background, culture and geography), the world of the text (genre, content, language, imagery) and the world in front of the text (reader experiences and reflections). These elements are vital for engaging learners in religious literacy and achieving the aims of the religious education program (Lutheran Education Australia, 2015).

4.3.1.3 Children's literature and contemporary story Gooderham's research (1994) contends the importance of using contemporary children's literature in the religious education classroom, inviting a Christian reading, and providing insight into the context of the Christian faith. Similarly, he speaks of fantasy texts, myths and legends of both Christian and traditional origin providing stimulation for learners to make their own meanings. He also notes that contemporary texts are increasingly structured to encourage questioning and invite discussion. Similarly, Robson (1982) promotes the use of contemporary literature in the religious education classroom to open discussion on matters of the Christian faith. Trousdale (2009) further advocates the use of children's literature as valuable for providing an opportunity for children to enter a different world and engage with characters to stimulate their emotions, imagination, cognitive development and moral reasoning. These stories can also allow children to connect with spiritual experiences beyond their own (Grajczonek \& Ryan, 2009; Shaw, 1999; Trousdale, 2009). Children's literature and contemporary story lend themselves to both the religious education and early childhood setting, and therefore it is important to identify connections teachers have made between children's literature and a religious education curriculum.

4.3.1.4 Cultural and traditional story The diverse cultural and religious perspectives in our communities are also reflected in religious education classes. Children may bring their personal story to their reading experiences through their histories, languages and generational perspectives of the world and of the text (Grajczonek, 2017; Green \& Oldendorf, 2005; Shaw, 1999). It is this diversity which brings a rich range of perspectives to the classroom and therefore, a range of opinions and ideas to consider when using story (Davila, 2015; Jacobs-Sife, 2011; Lutheran Education Australia, 2015; Mallan, 2014). Research also shows that sharing high quality picture books enables the expansion of knowledge and understanding of different faiths, through the communication of accurate information, in an interesting and engaging way, which allows the development of respect for diversity (Green \& Oldendorf, 2005; Renck-Peyton \& Renck-Jalongo, 2008). Investigating biblical text from their own perspective allows learners to explore why a story took place and how the world worked within the story, leading to discussions on how this may be similar or different to their own experiences, and the experiences of their peers (Madden et al., 2019; Shaw, 1999). Further research reveals that children's religious sense is nourished by a variety of stories and images from their Christian and cultural heritage and that this is important for their development of bicultural/ multicultural identity (Greer Anne Wenh-In Ng, 2004; Trousdale, 2009). According to Watson and Thompson (2007) religious myth and story allow the listener to use their imagination to recreate religious truths. They further emphasise the importance of developing imagination in religious education as essential for understanding religious language and developing religious concepts (Watson \& Thompson, 2007). Similarly, faith expressed through stories, can help children comprehend deep truths and explore abstract ideas (Cleary \& 
Moffat, 2017; Fisher, 2010). The Christian story, as it is lived out in the faith community is shaped by, and continues to shape, the identity of that community through its stories (Shaw, 1999). Together these studies reveal the importance of story for connection to culture and tradition, echoing the significance of sociocultural theory which underpins religious education, connecting a diverse range of perspectives with the Christian worldview, and the contribution it makes to building respect and appreciation of other's views.

4.3.1.5 Contribution to faith practice Stories in religious education can allow learners to engage with theology, investigating key Christian beliefs and worldviews (Lutheran Education Australia, 2015; Shaw, 1999). Focusing on both the cognitive and affective domains, Lutheran Education Australia's Christian Studies curriculum engages students in an opportunity to explore their own faith. The stories used in Christian Studies, whether biblical or non-biblical text, can provide a means by which children can be introduced to the world of religion and spirituality. Opportunities need to be provided to enable learners to engage deeply with the language, symbols and imagery, beyond superficial familiarity with biblical stories (Blevins, 2007). Teachers must be mindful of more than just telling a story well; these stories must contribute to the lives of those who hear and participate. Similarly, as Hansell (2015) observed, story is closely related to faith and an understanding of story is central to religious education, to take learners beyond lower order thinking, to a deep understanding.

Major religions have their own collections of stories which pass on their heritage and reveal deeper aspects of their beliefs (Leary, 1986). Further to this, Goldburg (2008) expounds the value of connecting the Christian story with the children's own stories, bringing meaning to their experiences and reflections. Stories are used to shape morals, make personal connections, build empathy and help learners to understand their own experiences to make sense of their world (Crain, 2007; Mudiyanselage, 2014; Rue, 2000; Ryan, 2007). Larson's research (2018) with preschool children which explored how they made meaning of their life and faith experiences through story, play and discovery, is echoed in the Early Years Learning Framework (Council of Australian Governments, 2017). Stories provided a narrative framework in which children could explore biblical story, providing a rich sense of self and experiences. This is also supported by Seymour (2007) who believes stories help us make (and remake) meaning in our lives and when used in religious education can help us to teach and build community. This is especially important in early childhood where people's images of God are formed early in life (Bartkowski et al., 2008). As children themselves become storytellers, they learn about themselves and their own lived religious experiences, developing strategies for living out their faith (Shaw, 1999). According to Shaw (1999), this is what makes story so important in religious education, and feedback and time for critical reflection are essential for learning to happen.

Brendan Hyde's (2010) exploration into Godly Play in the Catholic school context also revealed the insights this story telling technique provided on children's spirituality. Godly Play was developed by Jerome Berryman based on the Montessori method of teaching. The process involves engagement with biblical storytelling through play, wonder and response in a specific, organised way, modelling the Christian community. It goes beyond mere storytelling and recall, and invites learners to engage with story in a creative and experiential way. Berryman developed and refined his work based on his observations and studies, noting the powerful influence it had on children's spirituality (Berryman, 1991). The process invites children to engage with the story and consider questions about the story 
and how they relate to it (Trousdale, 2009). Through case study interviews, Hyde explored children's perceptions of spirituality revealing four characteristics which are encouraged through Godly Play: the felt sense, integrating awareness, weaving the threads of meaning and spiritual questing. The felt sense involves the way in which a child uses their body as a way of knowing, aware through tactile and sensory activities. Integrating awareness refers to connecting knowing or emerging understanding with a previous level of awareness. Hyde's third concept of weaving the threads of meaning, refers to the child's use of their sense of wonder, to make sense of the world around them. Finally, his concept of spiritual questing refers to children actively seeking a sense of the meaning and purpose of life.

Similarly, using the same context as Hyde's research, Grajczonek and Truasheim's (2017) study on Godly Play revealed it provided worthwhile strategies and resources for story telling however, they advised caution in using Godly Play due to the differences in theological underpinning and the protestant emphasis. The focus of these studies was on the faith and spiritual development and the role of story in these areas. As Grajczonek and Truasheim reveal, the use of Godly Play is not a curriculum structure for teaching religious education, and so must be used in an appropriate context as it was intended. As these studies show, story contributes to faith practice through engagement and connection to life and faith experiences, bringing meaning to learners' experiences and reflections.

\section{Discussion}

This systematic literature review scopes the research which connected three key areas: early childhood and story and religious education. While a vast amount of research is available in each specific key area, the research with a strong connection to all three was very limited, with few examples linked to a primary school curriculum. Benefits of the use of story are seen across curriculum areas in the early childhood sector with particular focus on spiritual development and biblical literacy in religious education. Stories can be told in a variety of ways and therefore the literature upon which educators draw must include a range of storytelling methods including reading a story aloud, digital/ audio-visual stories or games, dramatic storytelling including role play and puppetry, and Godly Play, and explore how teachers use different story telling methods in religious education. Similarly, as the Bible is a primary source for religious education and biblical story used extensively, the literature must also explore how teachers use biblical story within their lessons and investigate choices they make regarding pedagogy. This systematic review highlighted gaps in the research and further links can be made on the use of story in religious education through the exploration of teacher perceptions concerning integration of story, to highlight pedagogical choices and practices. Similarly further exploration and research could be conducted on how story embedded in a curriculum contributes to faith practice (or expression of the Christian faith) and how story influences the learner's understanding of the theology which underpins the curriculum.

\subsection{Limitations of the literature review}

There are limitations to this systematic quantitative literature search as a review of the available literature on the broad topics of early childhood, story and religious education, given the specific research question to which the search relates, and therefore the initial parameters of the search. A further literature search will follow this review with a particular 
focus on research from the last two years to capture the use of more recent technological advances and reflect the movement of schools worldwide to online learning as a response to social distancing and isolation regulations to mitigate the impact of pandemics such as COVID-19. The move to online learning consequently affected classroom delivery of lessons and the impact of this change is yet to be fully realised. A consideration must be made therefore on the use of digital storytelling as a feature of classroom practice. As Cruz and Snider (2009) note, it is important to connect with technology in multiple contexts including the use of story and this is worthy of further investigation. This is an area which will prove to be an interesting point of reflection to identify teachers' perceptions, and if, or how the move to online remote learning has impacted their practice. A search of the same databases will be conducted to reveal if further papers should be considered as possibly relevant to the research reflecting the global modification to schooling as a response to a pandemic such as COVID-19.

\section{Conclusion}

This paper provided a Systematic Quantitative Literature Review [SQLR] of the use of story in early childhood religious education to address the research question "What are the pedagogical benefits of using story in religious education in the early years of primary school?" Literature on the key areas of religious education, story and early childhood were reviewed for relevance and connection to the topic. The selected literature revealed story as an effective and pedagogically appropriate way of engaging children in religious education in early childhood. The use of story supports learner-centred pedagogy; encouraging active, engaged learners who make connections through story to build literacy, enhance social skills and collaboration, and engage in critical thinking and inquiry.

Story can be used in religious education in a pedagogically appropriate way, developing religious literacy and encouraging children to connect to the curriculum to meet learning outcomes. The research on story in religious education focuses on the benefits of story such as fostering faith and spiritual development, providing connection to culture and tradition, and building empathy through experiencing story. Further research could focus on the use of story as a pedagogical support to connect known benefits of story with the curriculum to develop literacy (including biblical literacy), effectively engage with diverse perspectives and contribute deeper understanding. This will provide a point for further teacher reflection on their current practice, drawing on theory of early childhood and religious education and their potential impact in Religious Education.

\section{References}

Anderson, J., Moffatt, L., \& McTavish, M. (2012). Rethinking language education in early childhoodSociocultural perspectives. Early Childhood Educational Curriculum and Instruction; Handbook of Research on the Education of Young Children.

Anderson, P. (2015). Teaching Reading in the Early Years. Australian Council for Educational Research. Retrieved July 21, from https://rd.acer.org/article/teaching-reading-in-the-early-years

Arthur, C. J. (1988). Some arguments for the use of stories in Religious Education. British Journal of Religious Education, 10(3), 122-127.

Bartkowski, J. P., Xu, X., \& Levin, M. L. (2008). Religion and child development: Evidence from the early childhood longitudinal study. Social Science Research, 37(1), 18-36. 
Berryman, J. W. (1991). Godly play an imaginative approach to religious education. HarperSanFrancisco.

Blevins, D. G. (2007). Story telling or storied telling? Media's pedagogical ability to shape narrative as a form of "knowing." Religious Education, 02(3), 250-263.

Boyd, W., \& Cutcher, L. (2015). Learning from early childhood philosophy, theory and pedagogy: Inspiring effective art education. Australian Journal of Early Childhood, 40(1), 91-98.

Carroll-Lind, J., Smorti, S., Ord, K., \& Robinson, L. (2016). Building pedagogical leadership knowledge in early childhood education. Australasian Journal of Early Childhood, 41(4), 28-35.

Casson, A. (2011). The right to "bricolage": Catholic pupils' perception of their religious identity and the implications for Catholic schools in England. Journal of Beliefs and Values, 32(2), 207-218.

Catholic Education Council. (2001). Policy Statement for Brisbane Catholic Schools-Early Years.

Child Australia. (2017). What is Pedagogy? How does it influence our practice? https://childaustralia.org. au/wp-content/uploads/2017/02/CA-Statement-Pedagogy.pdf.

Christenson, T. (2004). The gift and task of Lutheran higher education. Augsburg Fortress.

Christian, B. J. (2008). I love to tell the story. Teach Journal of Christian Education, 2(2), 4-7.

Cleary, A., \& Moffat, S. (2017). Curriculum focus K-2 religious education in the Archdiocese of Sydney. In R. Rymarz \& A. Belmonte (Eds.), Religious education in Australian Catholic Schools (pp. 305-325). Vaughan Publishing.

Cohrssen, C., Niklas, F., Logan, D., \& Tayler, C. (2016). The self-reported academic self-concept of fouryear-old children: Global and fixed, or nuanced and changing in the year before school? Australasian Journal of Early Childhood, 41(3), 4-10. https://doi.org/10.1177/183693911604100302

Council of Australian Governments. (2010). Educators' guide to the early years learning framework for Australia.

Council of Australian Governments. (2017). Belonging, being and becoming-The early years learning framework for Australia.

Crain, M. A. (2007). Reconsidering the power of story in religious education. Religious Education, 102(3), 241-284.

Cruz, F. M. F., \& Snider, S. L. (2009). Storying with technology: An approach to connect children and adults using the new technology and media landscape. Contemporary Issues in Early Childhood, 10(4), 378-388.

Dalton, R. W. (2007). Perfect Prophets, Helpful Hippos, and Happy Endings: Noah and Jonah in Children's Bible Storybooks in the United States. Religious Education, 102(3), 298-313. https://doi.org/10.1080/ 00344080701496272

Davila, D. (2015). \#WhoNeedsDiverseBooks?: Preservice teachers and religious neutrality with children's literature. Research in the Teaching of English, 50(1), 60-83.

Department of Education and Training. (2015). Age-appropriate pedagogies for the early years of schooling: Foundation paper. Q. Government. https://earlychildhood.qld.gov.au/early-years/age-appropriatepedagogies

Ewing, R., \& Saunders, J. N. (2016). The school drama book. Currency Press Pty Ltd.

Fisher, B. J. (2010). Developing a faith-based education: A teacher's manual. David Barlow Publishing.

Freitas, D. (2005). The big questions: A professor links children's literature to religious imagination. School Library Journal.

Goldburg, P. (2004). Towards a creative arts approach to the teaching of religious education with special reference to the use of film. British Journal of Religious Education, 26(6), 175-184.

Goldburg, P. (2008). Teaching religion in Australian schools. Numen, 55(2/3), 241-271.

Gooderham, D. (1994). Participation and distanciation: contemporary children's and adolescent literature in religious education. British Journal of Religious Education, 16(3), 164-173.

Grajczonek, J. (2007). Teaching the gospels with process drama. In J. G. M. Ryan (Ed.), Religious education in early childhood: A reader (pp. 116-124). Lumino Press.

Grajczonek, J. (2013). The early years religion program placing the emphasis on HOW young children learn. Religious Education Journal of Australia, 29(2), 3-8.

Grajczonek, J. (2017). Developing religious education curricula for early childhood in Australia. In R. Rymarz \& A. Belmonte (Eds.), Religious education in Australian Catholic schools exploring the landscape (pp. 99-118). Vaughan Publishing.

Grajczonek, J., \& Hanifin, P. (2007). Teaching and learning in the early years religion class. In J. G. M. Ryan (Ed.), Religious education in early childhood (pp. 158-176). Lumino Press.

Grajczonek, J., \& Ryan, M. (2009). Integrating children's literature into the classroom religion program. Journal of Religious Education, 57(4), 29-37.

Grajczonek, J., \& Truasheim, M. (2017). Implementing Godly Play in educational settings: A cautionary tale. British Journal of Religious Education, 39(2), 172-186. 
Green, C., \& Oldendorf, S. B. (2005). Teaching religious diversity through children's literature. Childhood Education, 81(4), 209-218.

Hansell, N. (2015). Memory, learning and story. Dialogue Australasia, 33, 23-25.

Hateley, E. (2014). Touching texts: Adaptations of Australian picture books for tablets. In K. Mallan (Ed.), Picture books and beyond (pp. 108-112). Primary English Teaching Association Australia.

Hoopes, M. L. (2013). The Power of Story in the Spiritual Development of Children (Publication Number 3589727) Biola University.

Hyde, B. (2005). Identifying some characteristics of children's spirituality in Australian Catholic primary schools: A study within hermeneutic phenomenology. Fitzroy: Australian Catholic University.

Hyde, B. (2010). Godly play nourishing children's spirituality: A Case Study. Religious Education, 105(5), 504-518. https://doi.org/10.1080/00344087.2010.516215

Hynes-Berry, M. (2012). Don't leave the story in the book: Using literature to guide inquiry in early childhood classrooms. Teachers College Press.

Jacobs-Sife, D. (2011). 'To throw alongside of' -Storytelling in the Primary Classroom. Dialogue Australasia (25): 29-32.

Jones, R. A., Gowers, F., Stanley, R. M., \& Okely, A. D. (2017). Enhancing the effectiveness of early childhood educators and researchers working together to achieve common aims. Australasian Journal of Early Childhood, 42(1), 81-84.

Kilderry, A. (2015). Intentional pedagogies: Insights from the past. Australasian Journal of Early Childhood, 40(3), 20-28.

Kim, Y. H. (2016). Early childhood educators' meta-cognitive knowledge of problem-solving strategies and quality of childcare curriculum implementation. Educational Psychology, 36(4), 658-674. https://doi. org/10.1080/01443410.2014.934661

Laminack, L. (2016). Story matters. The Reading Teacher, 70(2), 250-253.

Larson, M. (2018). Making meaning of God. Lutheran Education Journal. https://lej.cuchicago.edu/categ ory/church-work-professional/

Leary, C. (1986). Parables and fairytales. Religious Education, 81(3), 485-499.

Leggett, N., \& Newman, L. (2017). Play: Challenging educators' beliefs about play in the indoor and outdoor environment. Australasian Journal of Early Childhood, 42(1), 24-32. https://doi.org/10.23965/ AJEC.42.1.01

Liddy, S. A. (2009). Teaching Scripture in Religious Education. International Handbook of the Religious, Moral and Spiritual Dimensions in Education, 1361-1376.

Lillard, A. S. (1998). Playing with a theory of mind. In O. N. S. B. Spodek (Ed.), Multiple perspectives on play in early childhood education. State University of New York Press.

Lutheran Education Australia. (2013). A vision for learners and learning in Lutheran schools. Lutheran Education Australia.

Lutheran Education Australia. (2015). Christian Studies Curriculum Framework. Openbook.

Madden, R., France, A., O’Donnell, J., \& Butler, L. (2019). Pedagogy of encounter in the classroom. In R. Rymarz \& P. Sharkey (Eds.), Moving from theory to practice religious educators in the classroom (pp. 159-173). Vaughan Publishing.

Mallan, K. (2014). Introduction: Picture books... then, now and beyond. In K. Mallan (Ed.), Picture books and beyond (pp. 1-11). Primary English Teaching Association Australia.

McCrindle, M. (2014). The ABC of XYZ (3rd ed.). Mc Crindle Research Pty Ltd. (2009)

McCrindle, M. (2018a). Characteristics of the emerging generations. https://mccrindle.com.au/insights/ blogarchive/gen-Z-and-gen-alpha-infographic-update/

McCrindle, M. (2018b). What comes after Generation Z? Introducing Generation Alpha. Retrieved October 20, 2018, from https://mccrindle.com.au/insights/blogarchive/what-comes-after-generation-z-introducing-generation-alpha/

Meehan, C. (2007). Teachers' beliefs about religious education in the early years. In J. Grajczonek \& M. Ryan (Eds.), Religious education in early childhood: A reader (pp. 138-157). Paris: Lumino Press.

Mitchell, J. (2004). Teaching about worldviews and values. Council for Christian Education in Schools.

Moyles, J., Adams, S., \& Musgrove, A. (2002). SPEEL study of pedagogical effectiveness in early learning. Q. s. Printer.

Mudiyanselage, K. D. (2014). Encouraging empathy through picture books about migration. In K. Mallan (Ed.), Picture books and beyond (pp. 75-91). Primary English Teaching Association Australia.

Ness, M. (2016). When readers ask questions: Inquiry-based reading instruction. The Reading Teacher, 70(2), 189-196.

Ng, G.-I. (2004). Beyond Bible Stories: The role of culture-specific myths/stories in the identity formation of nondominant immigrant children. Religious Education, 99(2), 125-136. https://doi.org/10.1080/ 00344080490433701 
O’Neill, B., Banoobhai, M., \& Smith, C. (2016). Teaching literacy through dramatic storytelling in foundation phase. Australasian Journal of Early Childhood, 41(2), 95-102.

Pawson, E. (2014). Why stories and storytelling matter in RE. RE Today, Summer, 52.

Pickering, C., \& Byrne, J. (2014). The benefits of publishing systematic quantitative literature reviews for $\mathrm{PhD}$ candidates and other early-career researchers. Higher Education Research and Development, 33(3), 534-548. https://doi.org/10.1080/07294360.2013.841651

Pollock, K., Warren, J., \& Andersen, P. (2017). Inspiring environmentally responsible preschool children through the implementation of the National Quality Framework: Uncovering what lies between theory and practice. Australasian Journal of Early Childhood, 42(2), 12-19.

Punch, K. F. (2000). Developing effective research proposals. SAGE Publications Ltd.

Renck-Peyton, M., \& Renck-Jalongo, M. (2008). Make me an instrument of your peace: Honouring religious diversity and modeling respect for faiths through children's literature. Early Childhood Education Journal, 35, 301-303. https://doi.org/10.1007/s10643-007-0231-2

Richards, A. (2007). The story is just the start. Early Childhood News.

Robson, G. (1982). Religion for young humanists: Some religious themes in contemporary children's literature. British Journal of Religious Education, 4(3), 132-139. https://doi.org/10.1080/0141620820 040306

Rue, L. (2000). Everybody's story. State University of New York Press.

Ryan, M. (2007). Theorists informing early years religious education. In J. Grajczonek \& M. Ryan (Eds.), Religious education in early childhood a reader (pp. 32-43). Lumino Press.

Ryan, M., \& Stower, L. (1998). A vision of the whole child: The significance of religious experiences in early childhood. Australasian Journal of Early Childhood, 23(1), 1-4. https://doi.org/10.1177/18369 3919802300102

Rymarz, R., \& Engebretson, K. (2005). Putting textbooks to work: Empowering religious education teachers. British Journal of Religious Education, 27(1), 53-63.

Saracho, O. N. (2012). Views and Issues in Children's Literature. In O. N. Saracho \& B. Spodek (Eds.), Handbook of research on the education of young children. Routledge. https://search-credoreferencecom.ezproxy1.acu.edu.au/content/entry/routsmch/views_and_issues_in_children_s_literature/0

Schachter, L. (1985). Alternative to Bible stories for young children. Religious Education, 80(2), 308-313. https://doi.org/10.1080/0034408850800211

Seymour, J. (2007). Tell me a story. Religious Education, 102(3), 237-239.

Shaw, S. M. (1999). Storytelling in religious education. Religious Education Press.

Siegel-Hawley, G. (2012). How non-minority students also benefit from racially diverse schools. Research Brief, 8 .

Simpson, K. (2016). The Importance of Storytelling. Considered; The Faculty of Education blog. www. consider-ed.org.uk/the-importance-of-storytelling/

Siraj-Blatchford, I., \& Sylva, K. (2004). Researching pedagogy in English pre-schools. British Educational Research Journal, 30(5), 713-730.

Social Science Research Unit. (2019). What is a systematic review? UCL Institute of Education. Retrieved April 8, from https://eppi.ioe.ac.uk/cms/Default.aspx?tabid=67

Stack-Nelson, J. (2014). Beyond biblical literacy: Developing readerly readers in teaching biblical studies. Dialog: A Journal of Theology, 53(4), 293-303.

Trousdale, A. M. (2009). The Role of literature in children's spiritual development. International Handbook of the Religious, Moral and Spiritual Dimensions in Education, 1, 1225-1235. https://doi.org/10. 1007/1-4020-5246-4_86

Vygotsky, L. S. (1978). Mind in society. In M. Cole, V. John-Steiner, S. Scribner, \& E. Souberman (Eds.), The development of higher psychological processes. Harvard University Press.

Watson, B., \& Thompson, P. (2007). The effective teaching of religious education (2nd ed.). . Taylor and Francis.

Welbourne, L. (2003). Critical Biblical literacy in the School Curriculum. Journal of Religious Education, 51(4).

Zeece, P. D., Graul, S. K., \& Hayes, N. (2004). Stories for all children: The use of literature in inclusive early childhood classrooms. Early Childhood Education Journal, 31(4), 255-260.

Publisher's Note Springer Nature remains neutral with regard to jurisdictional claims in published maps and institutional affiliations. 